\title{
Determination of liver volume by the use of a gamma camera connected with 1600 or 4096 channel analyser in diffuse liver diseases
}

\author{
M. FUJII, T. MUKAI, T. YAMAMOTO, AND G. WAKISAKA \\ From the Central Clinical Radioisotope Division and First Department of Internal Medicine, Faculty of \\ Medicine, Kyoto University, Kyoto, Japan
}

SUMMARY A method of in vivo calculation of liver volume using a gamma camera and a 1600 or 4096 channel analyser is described. Topographically, the maximum thickness giving the highest counts in matrix data in the right anterior oblique projection is measured as the maximum breadth in the right posterior oblique projection. Then the total counts given by the liver can be transformed to the volume. The necropsy criteria indicated that the errors were between -11.9 to $+14.7 \%$ in 13 cases by the use of ${ }^{198} \mathrm{Au}$-colloid. In 20 selected normal control subjects, the mean of measured liver volumes was $779 \pm 99 \mathrm{~cm}^{3} / \mathrm{m}^{2}$ of surface area. The volumetric calculation using $99 \mathrm{mTc}$-Sn-colloid or ${ }^{99 m}$ Tc-phytate was compared with ${ }^{198} \mathrm{Au}$-colloid in the same patients. The results with ${ }^{99 m} \mathrm{Tc}-\mathrm{Sn}$ colloid were well correlated with those with ${ }^{198} \mathrm{Au}$-colloid, but the results with ${ }^{99 \mathrm{~m} T c}$-phytate and ${ }^{198} \mathrm{Au}$-colloid were almost equal. It was concluded that, excluding rare severe cases of liver cirrhosis, liver volume can be measured with reasonable accuracy.

The determination of liver size is often important in the diagnosis and prognosis of liver disease. However, it has been found that the clinical estimation of liver size, under certain conditions, gives erroneous results (Zelman, 1951; Fiorioli, 1953; Nimeh, 1955; Fleischner and Sayegh, 1958; Walk, 1961). Studies involving necropsy criteria have indicated the fallibility of clinical palpation as a basis for estimating liver size (Rives et al., 1937; Ratnoff and Patek, 1942; Reinberg and Lipson, 1950; Armas-Cruz et al.,1951). Detailed radiographic and clinical methods for the measurement of liver volume have been reported in the literature (Lutz, 1953; Fiorioli, 1953; Nimeh, 1955; Fiorioli, 1959; Walk, 1961). Although these are more accurate than routine clinical techniques, in some cases the border of the liver is not easily identified and special procedures are required to improve visibility.

In the field of nuclear medicine, several methods have been also described. Yagan et al. (1962) used the multiple cut-off scintillation scanning technique which considers the liver to be made up of trapezoids. Each separate trapezoid was integrated by planimetry. In 48 cases the comparison with post-mortem

Received for publication 9 January 1976 data indicated that the average deviation was $11.5 \%$. However, the technique was too laborious to be used routinely. In the method described by Rollo and DeLand (1968), the liver was assumed to be composed of an ellipsoid (right lobe) and a paraboloid (left lobe), and the volumetric calculation was made by using linear measurements obtained from anterior and lateral liver scans. However, it is difficult to make the above assumption in the presence of deformity, which is usually present in chronic diffuse liver diseases.

Several investigators have used for evaluation of liver size, cross-sectional areas from anterior liver scans (Naftalis and Leevy, 1963; MacAfee et al., 1965; Spencer and Banever, 1970). The measurements of the area can provide data in any configurations of the liver. Naftalis and Leevy (1963) demonstrated that scan size measured by planimetry correlated well with hepatic size at necropsy. However, when the anterior scan area is proportional to volume, the average thickness of each liver in the anteriorposterior direction should be the same. It remains to be determined to what extent scan area in the anterior-posterior direction represents volume of the liver. DeLand and North (1968), in their report of the examination of normal liver weight in 625 cases that 
came to necropsy, found no correlation between frontal surface area of the liver, frontal plus lateral surface area, and liver weight.

In this report, a simple method of determining liver volume by using a gamma camera and a 1600 or 4096 channel analyser is described.

\section{Method}

EQUIPMENT AND MATERIALS

Pho/Gamma III (Nuclear, Chicago) was connected with a 1600 or 4096 channel analyser. The nuclides used were ${ }^{198} \mathrm{Au}$-colloid (Dainabot Lab.), ${ }^{99 \mathrm{mTc}} \mathrm{T}$-Sncolloid (Dainabot Lab.), and ${ }^{99 m}$ Tc-phytate (Diagnostic Isotopes, Inc.).

\section{MEASUREMENT RATIONALE}

As shown by the transection at the 11th thoracic vertebra in Fig. 1, the liver image gives the maximum

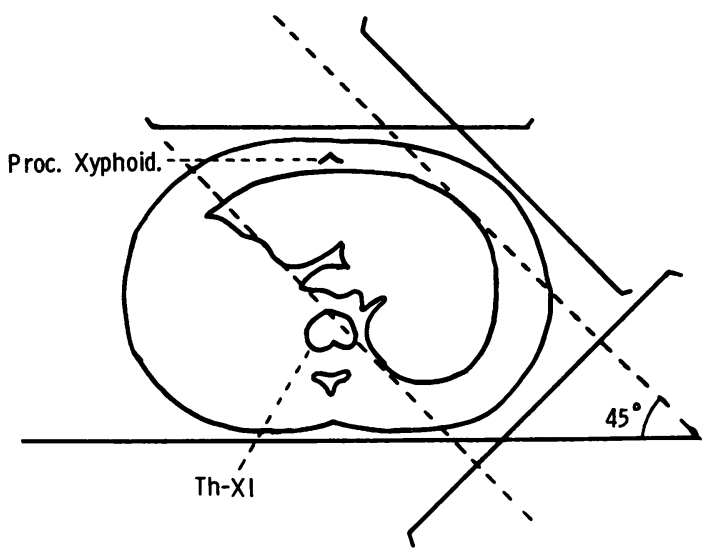

Fig. 1 Transection at the 11th thoracic vertebra.
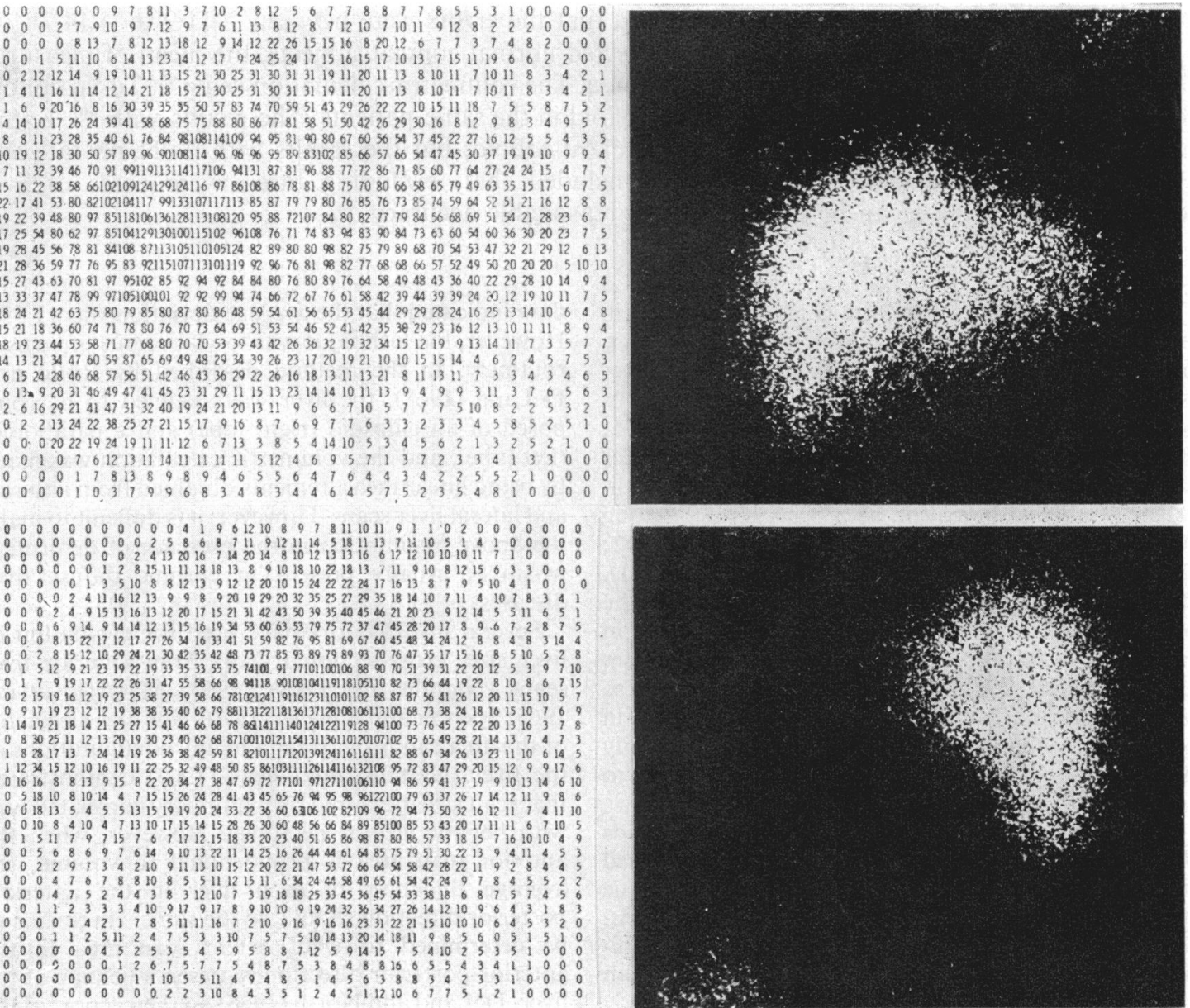

Fig. 2 Scintiphotos and numerical images $(40 \times 40$ matrix $)$ in the right anterior and right posterior oblique projections.

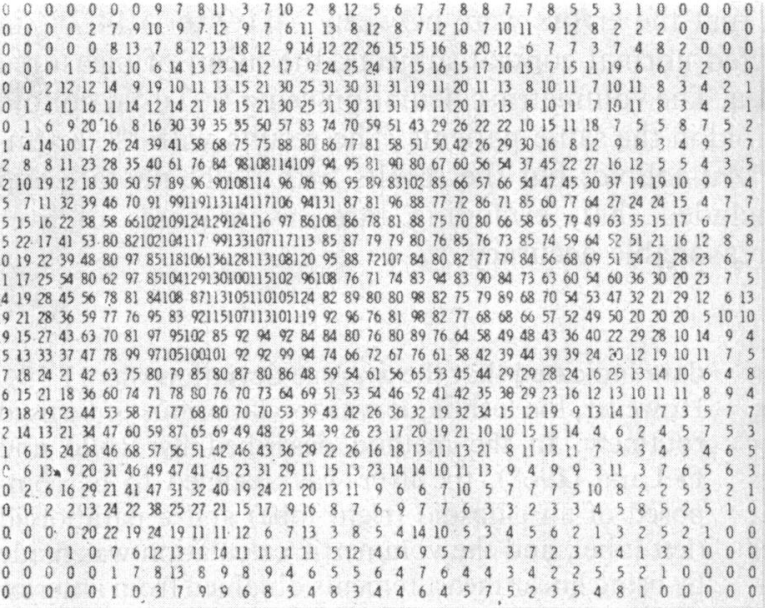


and minimum area in the right anterior oblique and right posterior oblique projections, while the maximum thickness of the liver in the right anterior oblique projection corresponds with the maximum width in the right posterior oblique projection. Then, as presented in Fig. 2, the thickness giving the maximum counts in matrix data in the right anterior oblique projection is measured as the maximum breadth in the right posterior oblique projection. Consequently, the total counts given by the liver can be transformed to the volume.

\section{CALCULATION OF LIVER VOLUME USING}

198 A U-COLLOID

Since ${ }^{99 \mathrm{~m}} \mathrm{Tc}$-Sn-colloid was not easily available to the present authors until recently, 150 to $200 \mu \mathrm{ci}{ }^{198} \mathrm{Au}$ colloid had been used for obtaining scintiphotos. The calculation of hepatic volume was made initially by the use of ${ }^{198} \mathrm{Au}$-colloid. After the injection of the above dose of ${ }^{198} \mathrm{Au}$-colloid, 50,000 counts were collected over the liver in right anterior oblique projection in the supine position, stored as a $40 \times 40$ matrix. It was thought that, for the volumetric calculation, amounts of low counts in the view field, which originated from extrahepatic removal of the colloid, had to be evaluated and subtracted from the total collected counts. The region of the liver in the $40 \times 40$ matrix was roughly determined by comparing the simultaneously obtained photograph in cases with no or only slight spleen visualization. The sum of the counts in the region other than the liver was obtained. In the examination of 41 cases this ranged from 3.33 to $14.62 \%$ of total counts with a mean value of 8.15 as listed in Table 1 . The value of $8 \%$ has been used routinely in the present laboratory.

The maximum width of liver image in the right posterior oblique projection was measured from a photograph using a ruler. As shown in Fig. 3, the dense part was assumed to be bordered.

A correction of peak counts for random-count fluctuations was necessary. A peak count was smoothed by the averaging of that value with the surrounding eight neighbours. Ratios of a mean of five or six peak counts to a mean of smoothed ones ranged from 0.82 to 0.94 with a mean value of 0.88 in 42 cases of a $5 \times 10^{4}$ collection. In 24 cases of a $2 \times 10^{4}$ collection the mean ratio was $0.80 \pm 0.18$ and in 14 cases of a $10 \times 10^{4}$ collection, $0.93 \pm 0.15$ was obtained.

Finally, the calculation of the volume of the liver was made by the following equation:

Volume $=\frac{\text { total net counts } \times 0.92}{\text { mean of five or six peaks counts } \times 0.88}$ $\times$ max. breadth in right posterior oblique projection $x$ one-cell area

where $\mathbf{0 . 8 8}$ is a constant for smoothing in the case of

\begin{tabular}{|c|c|c|}
\hline Case no. & Liver findings & $\%$ of total counts \\
\hline $71-023$ & Normal & $7 \cdot 90$ \\
\hline $71-024$ & Normal & 12.02 \\
\hline $71-028$ & Cirrhosis & 14.62 \\
\hline $71-032$ & Normal & $8 \cdot 79$ \\
\hline $71-039$ & C.H. & $10 \cdot 54$ \\
\hline 71-047 & C.H. & 9.89 \\
\hline $71-106$ & Cirrhosis & 5.81 \\
\hline $71-108$ & Cirrhosis & $9 \cdot 50$ \\
\hline $71-109$ & Cirrhosis & 12.90 \\
\hline $71-111$ & Cirrhosis & 7.97 \\
\hline $71-116$ & Normal & 6.07 \\
\hline $71-121$ & C.H. & $7 \cdot 16$ \\
\hline $71-128$ & Cirrhosis & 6.40 \\
\hline $71-129$ & C.H. & $5 \cdot 72$ \\
\hline $71-133$ & S.H. & $7 \cdot 27$ \\
\hline $71-138$ & S.H. & 6.07 \\
\hline $71-141$ & Fatty Liver & 4.83 \\
\hline $71-143$ & Cirrhosis & $6 \cdot 18$ \\
\hline $71-144$ & T.H. & 6.86 \\
\hline $71-147$ & Hepatomegaly & 6.86 \\
\hline $71-150$ & C.H. & 5.66 \\
\hline $71-151$ & C.H. & $9 \cdot 78$ \\
\hline $71-152$ & C.H. & 5.94 \\
\hline $71-158$ & C.H. & $\mathbf{7 \cdot 4 0}$ \\
\hline $71-159$ & S.H. & $7 \cdot 11$ \\
\hline $71-165$ & S.H. & $10 \cdot 60$ \\
\hline $71-172$ & C.H. & 3.75 \\
\hline $71-189$ & S.H. & $6 \cdot 30$ \\
\hline $71-190$ & S.H. & $9 \cdot 28$ \\
\hline $71-191$ & Cirrhosis & $5 \cdot 20$ \\
\hline $71-193$ & S.H. & 11.00 \\
\hline $71-212$ & S.H. & $10 \cdot 23$ \\
\hline $71-218$ & Congestion & 3.33 \\
\hline $71-221$ & Cirrhosis & $7 \cdot 35$ \\
\hline $71-226$ & C.H. & 12.56 \\
\hline $71-240$ & S.H. & $10 \cdot 14$ \\
\hline $71-252$ & C.H. & 7.92 \\
\hline $71-260$ & C.H. & $8 \cdot 83$ \\
\hline $71-261$ & Cirrhosis & $12 \cdot 80$ \\
\hline $71-277$ & Cholangitis & 6.90 \\
\hline $72-039$ & C.H. & 8.82 \\
\hline Total: 41 cases & \multicolumn{2}{|c|}{ Mean $\pm S D=8.15 \pm 2.61$} \\
\hline
\end{tabular}

C.H.: chronic hepatitis. S.H.: serum hepatitis. T.H.: toxic hepatitis.

Table 1 Evaluation of amounts of low counts from tissues other than liver in view field of gamma camera in right anterior oblique projection with use of ${ }^{198} \mathrm{Au}$-colloid

the $5 \times 10^{4}$ counts collection as described above. The value of 0.93 and 0.80 were used when the total collected counts were $10 \times 10^{4}$ and $2 \times 10^{4}$, respectively. When a 4096 channel analyser was used, about 15 peak counts were averaged. One-cell area was measured using five point sources forming a square with a $12 \cdot 7 \mathrm{~cm}(5 \mathrm{in}$.) diagonal and a centre, as shown in Fig. 4.

\section{Results}

COMPARISON OF in vivo CALCULATED LIVER VOLUME WITH POST-MORTEM WEIGHT

From January 1971 to February 1975 the in vivo calculation of liver volume was attempted in 1396 cases. Among them 13 cases are listed in Table 2 for a comparison with the weight at post-mortem exami- 


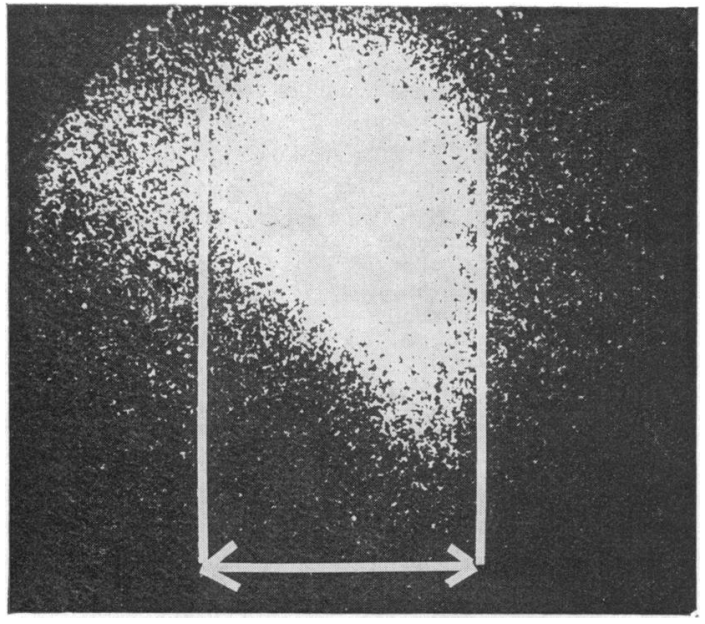

Fig. 3 The border used for measurements of the maximum breadth of liver image in the right posterior oblique projection.

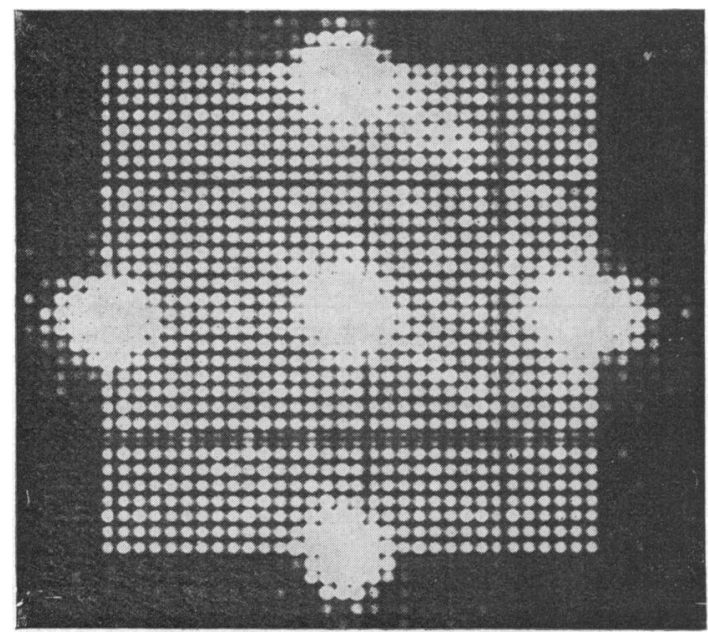

Fig. 4 Five points sources forming a square with a $12 \cdot 7 \mathrm{~cm}$ diagonal and a centre for the measurements of $a$ one-cell matrix area.

nation. In these cases the post-mortem examination was performed in less than six months after the in vivo calculation, during which no change of liver size was recorded in the clinical charts. The deviations from the liver weight at post-mortem examinations were between -11.9 to $+11.7 \%$ with the average of $6 \cdot 3 \%$.

RESULTS IN NORMAL CONTROL SUBJECTS Twenty-one subjects, ages ranging between 20 to 60 years, (11 males and 10 females) were selected as normal controls on the basis of the following criteria: (1) no history of liver disease or abnormal results from liver function tests; (2) no evidence of cardiovascular disease; (3) no evidence of systemic diseases of the liver, such as infection, lymphoma, leukaemia, or collagen disease.

The measured liver volumes ranged from 596 to $961 \mathrm{~cm}^{3} / \mathrm{m}^{2}$ of body surface area. The averaged value was $779 \pm 99 \mathrm{~cm}^{3} / \mathrm{m}^{2}$.

COMPARISON OF in vivo CALCULATIONS OF LIVER VOLUME BY USE OF ${ }^{198}$ AU-COLLOID, 99m TC-SN-COLLOID, AND 99m TC-PHYTATE In the present laboratory, ${ }^{198} \mathrm{Au}$-colloid has been used for measuring hepatic fractional clearance as an index of hepatic blood flow (Fujii et al., 1974). As mentioned above, because of the recent increase in availability, ${ }^{99 \mathrm{~m} T c-S n-c o l l o i d}$ or ${ }^{99 \mathrm{~m} T c-p h y t a t e}$ has since been used for obtaining scintigraphic image and about $20 \mu \mathrm{Ci}{ }^{198} \mathrm{Au}$-colloid for the measurement of hepatic fractional clearance. Among the patients given ${ }^{99 m} \mathrm{Tc}-S n$-colloid, 14 patients with no or only slight spleen and bone-marrow visualisation were selected and subjected to two volumetric calculations of the liver. Twenty-thousand counts were collected in the range of ${ }^{198} \mathrm{Au}$ activity and 50,000 counts in the range of $99 \mathrm{~m}$ Tc activity. The preset window of gamma camera (Pho/Gamma III) was $25 \%$ and 1000 hole collimator was used in both counts. In this study, smoothing of peak counts was made in each case after the numerical data of the image were read out. The results are shown in Table 3. In most of the cases, calculated liver volumes were greater in the range of ${ }^{99 m} \mathrm{Tc}$ activity than in the range of ${ }^{198} \mathrm{Au}$ activity.

With the use of ${ }^{99 \mathrm{~m} T c-p h y t a t e, ~ t h e ~ s a m e ~ c o m p a r i-~}$ sons were made in another 21 patients, cases with spleens greatly visible in the detector field being excluded. As shown in Table 4, the results of the two calculations were almost equal.

\section{Discussion}

DeLand and North (1968), in a study of 625 necropsies of adults without evidence of liver disease, reported that the relationship between liver weight and body surface area can be described by the equation: liver weight $(\mathrm{kg})=1.02$ body surface area $\left(\mathrm{m}^{2}\right)-\mathbf{0 . 2 2}$ and the relative standard deviation of liver weight was $16 \%$. According to this description, normal liver weight $(\mathrm{g})$ per surface area $\left(\mathrm{m}^{2}\right)$ can be estimated as $800 \pm 128 \mathrm{gm} / \mathrm{m}^{2}$.

In the present study, a sufficient number of determinations of liver volumes was not done in 


\begin{tabular}{|c|c|c|c|c|c|c|c|}
\hline $\begin{array}{l}\text { Case } \\
\text { no. }\end{array}$ & Patients & $\begin{array}{l}\text { Liver } \\
\text { volume } \\
\text { measured } \\
\text { in vivo } \\
(a)\left(\mathrm{cm}^{3}\right)\end{array}$ & $\begin{array}{l}\text { Liver } \\
\text { weight at } \\
\text { necropsy } \\
(\text { b })(g)\end{array}$ & $\begin{array}{l}\text { Difference } \\
a-b \\
b \\
(\%)\end{array}$ & $\begin{array}{l}\text { Interval } \\
\text { between } \\
(a)(b)\end{array}$ & $\begin{array}{l}\text { Liver } \\
\text { findings }\end{array}$ & $\begin{array}{l}\text { Dose of } \\
{ }^{198} \mathrm{Au} \text {-colloid } \\
(\mu \mathrm{Ci})\end{array}$ \\
\hline $\begin{array}{l}71-026 \\
72-071 \\
72-196 \\
72-276 \\
72-301 \\
72-328 \\
72-369 \\
72-554 \\
73-374 \\
73-451 \\
73-468 \\
73-480 \\
74-047\end{array}$ & $\begin{array}{l}\text { T.U. } \\
\text { S.K. } \\
\text { S.D. } \\
\text { T.K. } \\
\text { T.K. } \\
\text { R.S. } \\
\text { R.T. } \\
\text { K.O. } \\
\text { S.T. } \\
\text { K.O. } \\
\text { R.K. } \\
\text { H.O. } \\
\text { Y.I. }\end{array}$ & $\begin{array}{l}1830 \\
1525 \\
1445 \\
1558 \\
1717 \\
1656 \\
1372 \\
1140 \\
1461 \\
1778 \\
2174 \\
1807 \\
1628\end{array}$ & $\begin{array}{l}1770 \\
1300 \\
1280 \\
1530 \\
1805 \\
1800 \\
1300 \\
1150 \\
1355 \\
1910 \\
1970 \\
1860 \\
1670\end{array}$ & $\begin{array}{l}+2.8 \\
+14.7 \\
+11.4 \\
+1.9 \\
-4.9 \\
-11.9 \\
+5.5 \\
-0.8 \\
+7.8 \\
-6.9 \\
+4.6 \\
-2.8 \\
-2.5\end{array}$ & $\begin{array}{c}5 \cdot 8 \mathrm{M} \\
5 \cdot 8 \mathrm{M} \\
1 \cdot 3 \mathrm{M} \\
6 \mathrm{D} \\
2 \cdot 0 \mathrm{M} \\
3 \cdot 7 \mathrm{M} \\
5 \cdot 5 \mathrm{M} \\
4 \cdot 8 \mathrm{M} \\
7 \mathrm{D} \\
2 \cdot 4 \mathrm{M} \\
2 \cdot 0 \mathrm{M} \\
14 \mathrm{D} \\
5 \cdot 9 \mathrm{M}\end{array}$ & $\begin{array}{l}\text { Cholestasis } \\
\text { Cirrhosis } \\
\text { Portal cirrhosis } \\
\text { Congestive cirrhosis } \\
\text { Amyloidosis } \\
\text { Multiple myeloma } \\
\text { Leukemia } \\
\text { Amyloidosis } \\
\text { Acute hepatitis } \\
\text { Acute leukaemia } \\
\text { Acute leukaemia } \\
\text { Lymphosarcoma } \\
\text { Leukaemia }\end{array}$ & $\begin{array}{r}150 \\
150 \\
150 \\
150 \\
150 \\
150 \\
200 \\
200 \\
40 \\
20 \\
20 \\
15 \\
20\end{array}$ \\
\hline \multicolumn{8}{|c|}{ Mean $\pm S D: 6.3 \pm 4.3$} \\
\hline
\end{tabular}

Table 2 Comparison of in vivo calculated liver volumes with post-mortem weight

\begin{tabular}{|c|c|c|c|}
\hline \multirow{2}{*}{$\begin{array}{l}\text { Case } \\
\text { no. }\end{array}$} & \multicolumn{2}{|c|}{ Calculated volume by } & \multirow{2}{*}{$\begin{array}{l}\text { Calculation } \\
\text { ratios } \\
(b / a)\end{array}$} \\
\hline & $\begin{array}{l}{ }^{108} \mathrm{Au} \text {-colloid } \\
\text { (a) } \mathrm{cm}^{3}\end{array}$ & $\begin{array}{l}{ }^{90 \mathrm{~m}} T c-S n-\text {-colloid } \\
\text { (b) } \mathrm{cm}^{3}\end{array}$ & \\
\hline $73-489$ & 1578 & 1546 & 0.98 \\
\hline $73-490$ & 1063 & 1065 & 1.00 \\
\hline $73-495$ & 1494 & 1524 & 1.02 \\
\hline $73-496$ & 1389 & 1488 & 1.07 \\
\hline $74-114$ & 1187 & 1517 & $1 \cdot 28$ \\
\hline $74-118$ & 945 & 1131 & $1 \cdot 20$ \\
\hline $74-119$ & 1618 & 2067 & $1 \cdot 28$ \\
\hline $74-123$ & 1057 & 1303 & $1 \cdot 23$ \\
\hline $74-124$ & 913 & 1027 & $1 \cdot 13$ \\
\hline $74-128$ & 1237 & 1547 & $1 \cdot 25$ \\
\hline $74-129$ & 1120 & 1291 & $1 \cdot 15$ \\
\hline $74-156$ & 1707 & 1905 & $1 \cdot 12$ \\
\hline $74-161$ & 1650 & 2242 & $1 \cdot 36$ \\
\hline $74-164$ & 1792 & 2225 & $1 \cdot 24$ \\
\hline \multicolumn{4}{|c|}{$\begin{array}{l}\text { Total number of cases: } 14 \quad \text { Mean } \pm S D=1.16 \pm 0.12 \\
\text { Correlation coefficient between (a) and (b): } r=0.91(p>0.01)\end{array}$} \\
\hline
\end{tabular}

Table 3 Comparison of in vivo calculated liver volume with use of ${ }^{198}$ Au-colloid and ${ }^{99 \mathrm{~m}} \mathrm{Tc}$-Sn-colloid

normal subjects to establish an adequate range but the results compare favourably with the reported normal range.

The above-described method is based on the assumptions that the maximum thickness of the liver in right anterior oblique projection can be measured from a right posterior oblique projection on a scintiphotograph and that radioactive colloid is distributed evenly throughout the liver. In most cases, the site of the maximum thickness is found in the right lobe but in many severe cases of liver cirrhosis, the right lobe becomes atrophic and the site is found in the left lobe. In the latter cases, the thickness is possibly overestimated from a right posterior oblique projection. Uneven radioactivity within the lobe is found also in cases with an enhanced state of liver

\begin{tabular}{|c|c|c|c|}
\hline \multirow{2}{*}{$\begin{array}{l}\text { Case } \\
\text { no. }\end{array}$} & \multicolumn{2}{|c|}{ Calculated volume by } & \multirow{2}{*}{$\begin{array}{l}\text { Calculation } \\
\text { ratios } \\
(b / a)\end{array}$} \\
\hline & $\begin{array}{l}{ }^{198} \mathrm{Au} \text {-colloid } \\
\text { (a) } \mathrm{cm}^{3}\end{array}$ & $\begin{array}{l}{ }^{99} \mathrm{~m} T c-p h y t a t e \\
\text { (b) } \mathrm{cm}^{3}\end{array}$ & \\
\hline $\begin{array}{l}74-274 \\
74-275 \\
74-277 \\
74-279 \\
74-284 \\
74-285 \\
74-289 \\
74-292 \\
74-293 \\
74-295 \\
74-296 \\
74-297 \\
74-298 \\
74-299 \\
74-300 \\
74-302 \\
74-303 \\
74-304 \\
74-305 \\
74-308 \\
74-309\end{array}$ & $\begin{array}{r}1750 \\
1848 \\
1755 \\
1834 \\
1339 \\
1675 \\
1450 \\
1410 \\
1193 \\
1278 \\
1312 \\
1264 \\
1284 \\
1333 \\
938 \\
1319 \\
1569 \\
1742 \\
1557 \\
1215 \\
1367\end{array}$ & $\begin{array}{r}1820 \\
1783 \\
1637 \\
1571 \\
1273 \\
1618 \\
1440 \\
1228 \\
1193 \\
1329 \\
1325 \\
1328 \\
1409 \\
1368 \\
930 \\
1314 \\
1569 \\
1722 \\
1485 \\
1257 \\
1349\end{array}$ & $\begin{array}{l}1.040 \\
0.965 \\
0.933 \\
0.857 \\
0.951 \\
0.966 \\
0.933 \\
0.969 \\
1.000 \\
1.040 \\
1.010 \\
1.051 \\
1.097 \\
1.026 \\
0.992 \\
0.996 \\
1.000 \\
0.989 \\
0.954 \\
1.035 \\
0.987\end{array}$ \\
\hline \multicolumn{4}{|c|}{$\begin{array}{l}\text { Total number of cases: } 21 \quad \text { Mean } \pm S D=0.988 \pm 0.057 \\
\text { Correlation coefficient between (a) and (b); } r=0.93(P<0.01)\end{array}$} \\
\hline
\end{tabular}

Table 4 Comparison of in vivo calculated liver volume with use of ${ }^{198}$ Au-colloid and ${ }^{99 \mathrm{~m}}$ Tc-phytate

cirrhosis. In the present study, the peak counts were found in the left lobe in a case of amyloidosis (case no. 72-301), in which the difference between the in vivo calculation and the post-mortem examination was $-4.9 \%$. Uneven radioactivity was found in a case of liver cirrhosis (case no. 72-276), and the difference was $1.9 \%$. However, the accuracy of the method has not been tested in a sufficient number of such severe cases and greater error could occur with extremely advanced hepatic dysfunction. Increased radioactivity in tissues other than the liver is a 
source of error. This can be minimized by matrix area selection. However, since bone marrow is lying behind the liver, increased activities from the bone marrow, which commonly occur in patients with severe liver cirrhosis, cannot be fully removed by area selection. In those cases, error would be increased. However, in our opinion, it is in only a few of these cases that the calculated value would be considered unreliable.

The results of comparison of the use of ${ }^{198} \mathrm{Au}$ colloid with $99 \mathrm{~m} \mathrm{Tc}-\mathrm{Sn}$-colloid and $99 \mathrm{~m} \mathrm{Tc}$-phytate indicated that ${ }^{99 \mathrm{~m}} \mathrm{Tc}-\mathrm{Sn}$-colloid is distributed to extrahepatic and extrasplenic tissues in more considerable quantities than ${ }^{198} \mathrm{Au}$-colloid, making selection of liver area in a matrix necessary. The distributions of ${ }^{198} \mathrm{Au}$-colloid and ${ }^{99 \mathrm{~m}} \mathrm{Tc}$-phytate seem to be similar, and the same value of extrahepatic uptake ( $8 \%$ in most cases) can be used in the volumetric calculation.

The authors are indebted to Professor K. Torizuka, Department of Radiology, Faculty of Medicine, Kyoto University, for his help in this study. The authors wish to express thanks to the technicians in the Central Clinical Radioisotope Division of Kyoto University Hospital for their generous assistance throughout.

\section{References}

Armas-Cruz, R., Yazigi, R., Lopez, O., Montero, E., Cabello, J., and Lobo, G. (1951). Portal cirrhosis: an analysis of 208 cases, with correlation of clinical, laboratory and autopsy findings. Gastroenterology, 17, 327-343.

DeLand, F. H., and North, W. A. (1968). Relationship between liver size and body size. Radiology, 91, 1195-1198.

Fiorioli, W. (1953). Die klinische Auswertung des röntgenologischen Lebermessverfahrens. Medizinische Klinik, 48, 1138-1139.
Fiorioli, W. (1959). Berechnung des Lebergewichtes am Lebenden. Medizinische Klinik, 54, 254-255.

Fleischner, F. G., and Sayegh, V. (1958). Assessment of the size of the liver; roentgeologic considerations. New England Journal of Medicine, 259, 271-274.

Fujii, M., Yamamoto, T., and Wakisaka, G. (1974). Diagnosis of diffuse liver diseases based on the estimation of hepatic effective blood flow and volume, and on the findings of liver RI image using radioactive colloid. Proceedings of the 1 st World Congress on Nuclear Medicine, 492-494.

Lutz, P. (1953). Zur Technik der röntgenologischen Lebergrössenbestimmung. Medizinische Klinik, 48, 1137.

MacAfee, J. G., Ause, R. G., and Wagner, H. N., Jr. (1965). Diagnostic value of scintillation scanning of the liver. Archives of Internal Medicine, 116, 95-110.

Naftalis, J., and Leevy, C. M. (1963). Clinical estimation of liver size. American Journal of Digestive Diseases, 8, 236-243.

Nimeh, W. (1955). New method for the determination of the size of the liver and spleen. American Journal of Gastroenterology, 23, 147-156.

Ratnoff, O. D., and Patek, A. J., Jr (1942). The natural history of Laennec's cirrhosis of the liver; an analysis of 386 cases. Medicine (Baltimore), 21, 207-268.

Reinberg, M. H., and Lipson, M. (1950). The association of Laennec's cirrhosis with diabetes mellitus. Annals of Internal Medicine, 33, 1195-1202.

Rives, J. D., Romano, S. A., and Sandifer, F. M. (1937). Carcinoma of the pancreas. Surgery, Gynecology, and Obstetrics, 65, 164-177.

Rollo, F. D., and DeLand, F. H. (1968). The determination of liver mass from radionuclide images. Radiology, 91, 11911194.

Spencer, R. P., and Banever, C. (1970). Growth of the human liver: a preliminary scan study. Journal of Nuclear Medicine, 11, 660-662.

Walk, L. (1961). Roentgenologic determination of the liver volume. Acta Radiologica, 55, 49-56.

Yagan, R., MacIntyre, W. J., and Christie, J. H. (1962). Estimation of liver size by the multiple cut off scintillation scanning technique. American Journal of Roentgenology, 88, 289-295.

Zelman, S. (1951). Liver and spleen visualization by a simple roentgen contrast method. Annals of Internal Medicine, 34, 466-478. 